\title{
Comparative Studies on Extracellular Penicillinases of the Same Structural Gene, penP, Expressed in Bacillus licheniformis and Bacillus subtilis
}

\author{
By TADAYUKI IMANAKA, * WATARU OSHIHARA, TAKESHI HIMENO \\ AND SHUICHI AIBA
}

Department of Fermentation Technology, Faculty of Engineering, Osaka University, Yamada-oka, Suita-shi, Osaka 565, Japan

(Received 15 December 1982; revised 9 March 1983)

\begin{abstract}
Extracellular penicillinases produced by Bacillus licheniformis ATCC 9945A and Bacillus subtilis from the same structural gene, pen $P$, were compared. The two strains secreted the same exolarge penicillinase (mol. wt, 30500 ; isoelectric point, $\mathrm{pI}=5 \cdot 00-5.04 ; \mathrm{NH}_{2}$-terminal amino acid, Ser). In contrast, the exo-small enzyme from Bacillus subtilis (mol. wt, 29500; pI $=5 \cdot 00-5 \cdot 04$; $\mathrm{NH}_{2}$-terminal amino acid, Glu or Asn) was slightly different from that of Bacillus licheniformis (mol. wt, 29500; pI $=5.13 ; \mathrm{NH}_{2}$-terminal amino acid, Lys). The difference in the $\mathrm{NH}_{2}-$ terminal residue is most probably due to differences in degradation by host-specific proteolytic enzymes.
\end{abstract}

\section{INTRODUCTION}

By using vector plasmids, we have cloned the structural gene for penicillinase, pen $P$, from Bacillus licheniformis ATCC 9945A in Bacillus subtilis and B. licheniformis (Imanaka et al., 1981). Although both strains carrying the pen $P$ gene produced nearly the same total amount of penicillinase, the fraction of secreted penicillinase for $B$. subtilis and $B$. licheniformis amounted to around 30 and $60 \%$ of the total activities, respectively (Imanaka et al., 1981).

It has been reported that $B$. licheniformis $749 / C$, containing only a single structural gene for penicillinase (Sherratt \& Collins, 1973), produces both an extracellular penicillinase and a membrane-bound form which can be converted to the extracellular enzyme by proteolytic cleavage (Yamamoto \& Lampen, 1976). That prepenicillinase made in vitro was larger than the membrane-bound form (Sarvas et al., 1978), and that two related extracellular penicillinases, exo-large and exo-small, were present in a culture supernatant (Izui et al., 1980), is evidence of host-specific processing. The processing occurs by modification and cleavage of amino acid residues at the $\mathrm{NH}_{2}$-terminal sequence of the penicillinase (Simons et al., 1978; Smith et al., 1981).

The purpose of this paper is to demonstrate that peptide products from the same structural gene are processed differently by host-specific peptidases.

\section{METHODS}

Materials. Tetracycline, chloramphenicol and standard dansyl amino acids (arginine, glutamic acid, glycine and serine) were purchased from Sigma. Kanamycin and benzylpenicillin were from Meiji Seika Co., Tokyo, Japan. Restriction endonucleases (EcoRI, Pst I, Bg/II, Hinf I, HaeIII), T4 DNA ligase and T4 polynucleotide kinase were from Takara Shuzo Co., Kyoto, Japan. Yeast extract, Bacto-tryptone and Casamino acids were from Difco. Ampholine ( $\mathrm{pH} 4-6 ; 3-10)$ was from LK B, Sweden. Protein molecular weight standards were from Boehringer Mannheim. Low melting point agarose was from Bethesda Research Laboratories, Maryland, U.S.A. Cellulose phosphate Pl was from Whatman. Carboxymethylcellulose was from Serva Feinbiochemica, Heidelberg, Germany. Sephadex G-100 was from Pharmacia. Polyamide layer sheet was from Seikagaku Kogyo Co., Tokyo, Japan. All other reagents were purchased from Wako Pure Chemical Industries, Osaka, Japan. 


\title{
Table 1. Bacterial strains and plasmids
}

Bacteria
Bacillus licheniformis
ATCC 9945A M015-1
Bacillus subtilis
MI112
Escherichia coli
C600-1
Plasmids
pTTB32
pTTE11

Properties*

\author{
pepAl penIIO penP8I penP83 $\mathrm{Sm}^{\mathrm{r}} \mathrm{Hl}^{-} \mathrm{Rec}^{-}$ \\ leuA8 arg-15 thr-5 recE4 $\mathrm{r}_{\mathrm{M}}{ }^{-} \mathrm{m}_{\mathrm{M}}^{-}$ \\ leu-6 thr-1 thi-1 supE44 lacY1 tonA21 hsdR hsdM Trp- \\ $\mathrm{Km}^{\mathrm{r}}$ penP $\mathrm{P}^{+}$penI10 \\ $\mathrm{Tc}^{\mathrm{r}}$ pen $P^{+}$penIIO
}

* See Imanaka et al. (1981) for details. Sm, Streptomycin; Km, Kanamycin; Tc, Tetracycline.

Bacterial strains and plasmids. Strains and plasmids used in this work are listed in Table 1. Both B. licheniformis ATCC 9945A M015-1 and $B$. subtilis MI112 are recombination deficient and do not produce any detectable penicillinase. Penicillinase genes from a constitutive strain of $B$. licheniformis ATCC 9945A have been cloned in Escherichia coli with pMB9 $\left(\mathrm{Tc}^{\mathrm{r}}\right)$ as vector plasmid, and the cloned genes were transferred into Bacillus strains with pTB53 $\left(\mathrm{Km}^{\mathrm{r}} \mathrm{Tc}^{r}\right)$. These recombinant plasmids were designated as pTTE11 and pTTB32, respectively (Imanaka et al., 1981).pen $P$ and penI are, respectively, the structural gene and the repressor gene for penicillinase, and are coded on the same EcoRI fragment (2.8 MDal, Imanaka et al., 1981).

Media. L broth contained $10 \mathrm{~g}$ Bacto-tryptone, $5 \mathrm{~g}$ yeast extract, and $5 \mathrm{~g} \mathrm{NaCl}$ in 1 litre of deionized water; it was adjusted to $\mathrm{pH} 7 \cdot 0$ with $\mathrm{NaOH}$ and solidified with $15 \mathrm{~g}$ agar per litre. Kanamycin $\left(5 \mu \mathrm{g} \mathrm{ml}^{-1}\right)$ and tetracycline $\left(20 \mu \mathrm{g} \mathrm{ml}^{-1}\right)$ were added to $\mathrm{L}$ broth to ensure plasmid stability for Bacillus strains carrying pTTB32 and E. coli

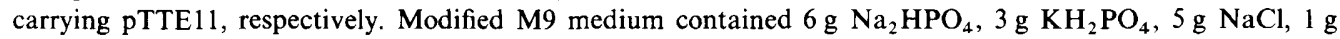
$\mathrm{NH}_{4} \mathrm{Cl}, 20 \mathrm{~g}$ Casamino acids, $0 \cdot 2 \mathrm{~g}$ glucose, $0 \cdot 1 \mathrm{~g} \mathrm{MgSO} \cdot 7 \mathrm{H}_{2} \mathrm{O}, 15 \mathrm{mg} \mathrm{CaCl}{ }_{2} .2 \mathrm{H}_{2} \mathrm{O}$ and $10 \mathrm{mg}$ thiamin in 1 litre of deionized water (Imanaka et al., 1980). CH/S medium (Pollock, 1965) contained Casamino acids $\left(10 \mathrm{~g} \mathrm{l}^{-1}\right.$ ), $\mathrm{KH}_{2} \mathrm{PO}_{4}\left(2 \cdot 8 \mathrm{~g} \mathrm{l}^{-1}\right)$ and salt solution.

Penicillinase assay. Penicillinase was assayed by the iodometric method as described previously (Imanaka et al., 1981). One unit of penicillinase was defined as the quantity required to hydrolyse $1 \mu$ mol benzylpenicillin per $h$ at $30{ }^{\circ} \mathrm{C}$.

Protein assay. Protein concentration was measured by the Lowry method using bovine serum albumin as standard.

Preparation of extracellular penicillinase. The procedure described by Yamamoto \& Lampen (1976) was used to purify extracellular penicillinase, except that the culture broth was directly adjusted to $\mathrm{pH} 5 \cdot 0$ without alkaline ( $\mathrm{pH}$ 9.0) treatment. Host strains (B. licheniformis and B. subtilis) carrying pTTB32 were cultivated to the end of the exponential growth phase in $\mathrm{CH} / \mathrm{S}$ medium $(5 \mathrm{l}$ ) in a $10-1$ fermenter, and the cells were removed by centrifugation $(10000 \mathrm{~g}, 10 \mathrm{~min})$. The supernatant liquid was adjusted to $\mathrm{pH} 5.0$ with acetic acid.

The following purification procedures were carried out at about $4{ }^{\circ} \mathrm{C}$. Phosphocellulose (Whatman $\mathrm{P} 1, \mathrm{H}^{+}$form) was added to the supernatant (final concentration, $10 \mathrm{~g}^{-1}$ ) and the suspension was gently stirred overnight. The phosphocellulose was collected and washed twice with $0.01 \mathrm{M}-\mathrm{KH}_{2} \mathrm{PO}_{4} / \mathrm{NaOH}(\mathrm{pH} 5 \cdot 0)$, and the adsorbed enzyme was eluted with $0.2 \mathrm{M}-\mathrm{KH}_{2} \mathrm{PO}_{4} / \mathrm{NaOH}(\mathrm{pH} 7 \cdot 6)$. The enzyme solution was adjusted to $\mathrm{pH} 4.8$ with acetic acid, and was dialysed overnight against $0.01 \mathrm{M}$-ammonium acetate buffer ( $\mathrm{pH} 4.8$ ). The enzyme solution was applied to a carboxymethylcellulose column $(2.5 \times 20 \mathrm{~cm})$ equilibrated against $0.01 \mathrm{M}$-ammonium acetate buffer (pH 4.8) and the column was washed with three volumes of the same buffer. The column was eluted with a 1-litre linear gradient of $0.01 \mathrm{M}, \mathrm{pH} 4.8$ to $0.3 \mathrm{M}, \mathrm{pH} 8.5$, ammonium acetate buffer. Enzyme fractions were pooled in a dialysis tube and dehydrated in polyethylene glycol solution. The concentrated solution was applied to a Sephadex G-100 column $(2.5 \times 100 \mathrm{~cm})$ which had been equilibrated with $0.01 \mathrm{M}$-ammonium acetate buffer, $\mathrm{pH} 8 \cdot 0$, and eluted with the same buffer.

$S D S-P A G E$. To determine the molecular weight of the enzyme, the continuous SDS system of Weber \& Osborn (1969) was used. The gel was $7 \cdot 5 \%(\mathrm{w} / \mathrm{v})$ polyacrylamide. The discontinuous SDS system of Laemmli (1970) was also used, for which the gel was $12.5 \%$ polyacrylamide. Gels were fixed in $25 \%(\mathrm{w} / \mathrm{v}) \mathrm{TCA}$, stained in $0.5 \%$ Coomassie Brilliant Blue R for $40 \mathrm{~min}$, and destained. The protein standards included $E$. coli RNA polymerase $\beta^{\prime}$ subunit (mol. wt 165000) and $\beta$-subunit (155000), bovine serum albumin (68000), RNA polymerase $\alpha$-subunit (39000), trypsin inhibitor (21500) and cytochrome $c$ (12500).

Isoelectric focusing. Sucrose density gradient $(0-50 \%)$ electrofocusing of penicillinase was performed by using a $110 \mathrm{ml}$ vertical column. Ampholine ( $\mathrm{pH} 4-6 / \mathrm{pH} 3-10 ; 4: 1)$ was added [final concentration $1 \%(\mathrm{w} / \mathrm{v})$ ]. The anode strip was saturated with $1 \mathrm{M}-\mathrm{H}_{3} \mathrm{PO}_{4}$, and the cathode strip was saturated with $1 \mathrm{M}-\mathrm{NaOH}$. The protein was focused at a constant voltage, $600 \mathrm{~V}$ for $48 \mathrm{~h}$ at $0^{\circ} \mathrm{C}$. 
Determination of the $\mathrm{NH}_{2}$-terminal amino acid residue. The $\mathrm{NH}_{2}$-terminal amino acid residue of penicillinase was determined by using dansyl chloride (1-dimethylaminonaphthalene-5-sulphonyl chloride) (Gray, 1972). Dansyl derivatives of the $\mathrm{NH}_{2}$-terminal amino acid were spotted on one side of a polyamide sheet. A mixture of the sample and standard dansyl amino acids (dansyl-Arg, -Glu, -Gly, -Ser) was spotted on the reverse side, followed by two-dimensional TLC. The first solvent was $1 \cdot 5 \%(\mathrm{v} / \mathrm{v})$ formic acid, and the second was benzene/acetic acid $(9: 1$, $\mathrm{v} / \mathrm{v})$. The third separation was done with ethyl acetate/methanol/acetic acid (20:1:1, by vol.).

DNA sequencing. DNA sequencing was performed as described by Maxam \& Gilbert (1977). The DNA fragment sequenced was isolated from the $2.8 \mathrm{MDal} E c o$ RI fragment of recombinant plasmid pTTE11.

Other procedures. Preparation of plasmid pTTE11 from E. coli, digestion of plasmid DNA with restriction endonucleases, and agarose gel electrophoresis were carried out as described previously (Imanaka et al., 1980, 1981, 1982).

\section{RESULTS}

\section{Purification of extracellular penicillinase}

A typical enzyme purification from the culture supernatant of $B$. licheniformis ATCC 9945A M015-1 carrying plasmid pTTB32 is summarized in Table 2 . More than $90 \%$ of the total penicillinase activity in the culture supernatant was adsorbed by the phosphocellulose. Only a single peak of penicillinase activity was detected during the carboxymethylcellulose chromatography and after gel filtration on Sephadex G-100 (data not shown). The final recovery of purified penicillinase was $58 \%$. The specific activity of the purified enzyme, 350 units $(\mu \mathrm{g}$ protein $)^{-1}$, is similar to that previously reported for $B$. licheniformis $749 / C$ [330 units $(\mu \mathrm{g}$ protein $)^{-1}$, Pollock (1965); 355 units ( $\mu$ g protein $)^{-1}$, Yamamoto \& Lampen (1976); 330-350 units ( $\mu$ g protein $)^{-1}$, Simons et al. (1978)].

The purification of the extracellular penicillinase produced by B. subtilis MI112(pTTB32) is also summarized in Table 2 . The increase in specific activity during the purification was similar to that for the enzyme from $B$. licheniformis and the final specific activity of the purified penicillinase was virtually identical at 346 units $(\mu \mathrm{g} \text { protein })^{-1}$.

\section{Determination of molecular weight}

Purified extracellular penicillinases produced by both $B$. licheniformis and B. subtilis were subjected to SDS-polyacrylamide gel electrophoresis for the determination of molecular weight. The enzyme from each strain exhibited two protein bands at the same positions (Fig. 1, lanes B and C). The molecular weights for the two bands corresponded to 30500 and 29500 , respectively. Accordingly, the two proteins were considered to be the related extracellular penicillinases, exo-large and exo-small (Izui et al., 1980).

Table 2. Summary of purification of penicillinase

\begin{tabular}{|c|c|c|c|c|c|}
\hline Source & Fraction & $\begin{array}{c}10^{-6} \times \text { Total } \\
\text { enzyme activity } \\
\text { (units) }\end{array}$ & $\begin{array}{l}\text { Total } \\
\text { protein } \\
\text { (mg) }\end{array}$ & $\begin{array}{c}\text { Specific activity } \\
\text { [units }(\mu \mathrm{g} \text { protein })^{-1} \text { ] }\end{array}$ & $\begin{array}{l}\text { Yield } \\
(\%)\end{array}$ \\
\hline B. licheniformis & Supernatant & $14 \cdot 4$ & & & 100 \\
\hline ATCC $9945 \mathrm{~A}$ & Phosphocellulose treatment & $13 \cdot 5$ & 171 & 79 & 94 \\
\hline \multirow[t]{2}{*}{ M015-1(pTTB32) } & $\begin{array}{l}\text { Carboxymethylcellulose } \\
\text { chromatography }\end{array}$ & $12 \cdot 6$ & 43 & 290 & 88 \\
\hline & $\begin{array}{l}\text { Sephadex G-100 gel } \\
\text { filtration }\end{array}$ & $8 \cdot 4$ & 24 & 350 & 58 \\
\hline \multirow{4}{*}{$\begin{array}{l}\text { B. subtilis } \\
\text { MIII2(pTTB32) }\end{array}$} & Supernatant & $6 \cdot 31$ & & & 100 \\
\hline & Phosphocellulose treatment & $6 \cdot 15$ & 70 & 88 & 97 \\
\hline & $\begin{array}{l}\text { Carboxymethylcellulose } \\
\text { chromatography }\end{array}$ & $4 \cdot 33$ & 15 & 297 & 69 \\
\hline & $\begin{array}{l}\text { Sephadex G-100 gel } \\
\text { filtration }\end{array}$ & $3 \cdot 41$ & 10 & 346 & 54 \\
\hline
\end{tabular}




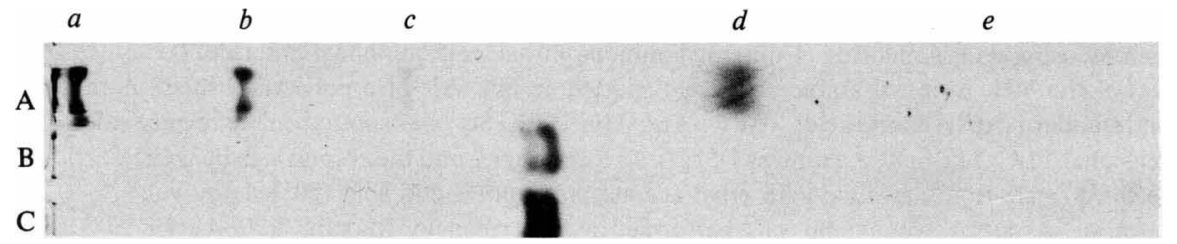

Fig. 1. SDS-PAGE of purified extracellular penicillinases. A, protein standards; $B$, penicillinase from B. licheniformis M015-1(pTTB32); C, penicillinase from B. subtilis MI112(pTTB32). Standards: $a, \beta^{\prime}$. subunit and $\beta$-subunit of RNA polymerase from $E$. coli (mol. wts 165000 and 155000 , respectively); $b$, bovine serum albumin (68000); $c$, RNA polymerase $\alpha$-subunit (39000); $d$, trypsin inhibitor (21 500); $e$, cytochrome $c(12500)$
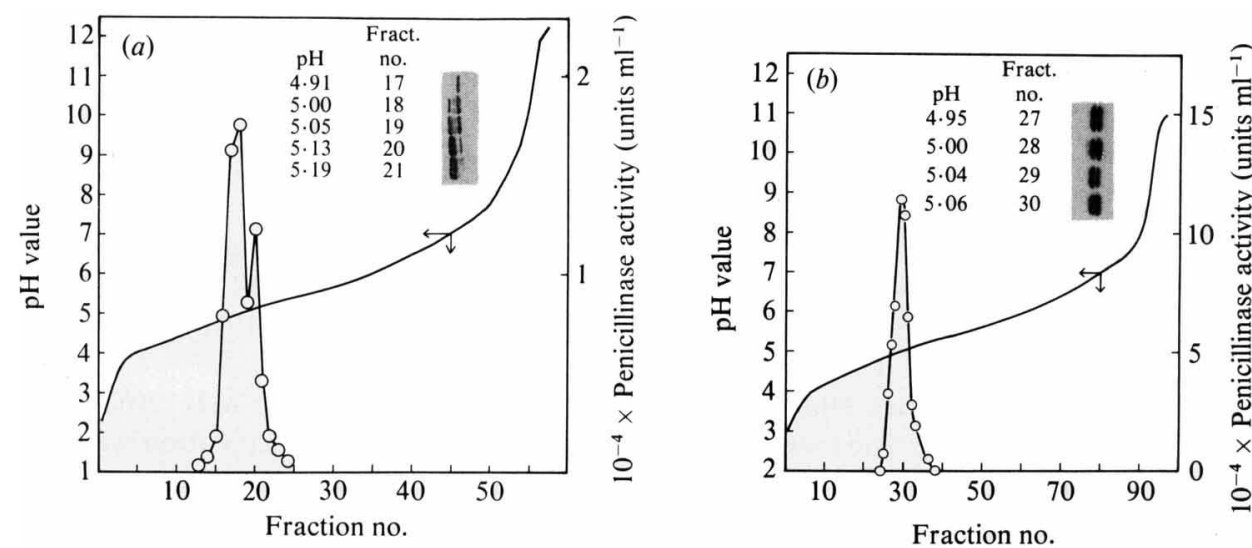

Fig. 2. Isoelectric focusing of purified penicillinase. (a) B. licheniformis M015-1(pTTB32), $2 \mathrm{ml}$ per fraction; (b) B. subtilis MI112(pTTB32), $1 \mathrm{ml}$ per fraction. $O$, penicillinase activity.

\section{Isoelectric focusing of extracellular penicillinases}

To separate the exo-large and exo-small penicillinases and determine their isoelectric points, isoelectric focusing of penicillinase was performed. Extracellular penicillinase from $B$. licheniformis showed two peaks of enzyme activity (Fig. 2a). It was confirmed by SDS-PAGE that the major peak (fraction $18, \mathrm{pH} 5 \cdot 00$ ) corresponded to an exo-large penicillinase, while the minor peak (fraction 20, pH 5.13) to an exo-small type (Fig. $2 a$ ).

Figure $2(b)$ shows isoelectric focusing of extracellular penicillinase from $B$. subtilis. A single peak of enzyme activity is apparent. It was also confirmed from SDS-PAGE that the peak (pH 5.00-5.04) was composed of both exo-large and exo-small penicillinases (Fig. $2 b$ ).

These results suggest that the penicillinases secreted by $B$. licheniformis and $B$. subtilis differed subtly and the difference was beyond the scope of detection by the SDS-PAGE (Fig. 1). Hence, a partial nucleotide sequence was determined to obtain information on the amino acid sequence at the $\mathrm{NH}_{2}$-terminus of the penP gene product.

\section{Nucleotide sequence of $\mathrm{NH}_{2}$-terminal region of penP}

Plasmid pTTE11 was extracted from $E$. coli and digested with restriction endonuclease $E c o$ RI. The $2.8 \mathrm{MDal}(4300 \mathrm{bp}) E c o$ RI fragment was separated by electrophoresis on a low melting point agarose gel $(1 \%)$. The region of the gel containing the $2.8 \mathrm{MDal}$ fragment was isolated, and the gel was melted at $65^{\circ} \mathrm{C}$ and extracted three times with phenol saturated with $0 \cdot 1 \mathrm{M}$-Tris/ $\mathrm{HCl}(\mathrm{pH} 8 \cdot 0$ ). To remove phenol, the water layer was treated with ether, and DNA was precipitated with ethanol. Since this fragment carrying pen $P$ from $B$. licheniformis 

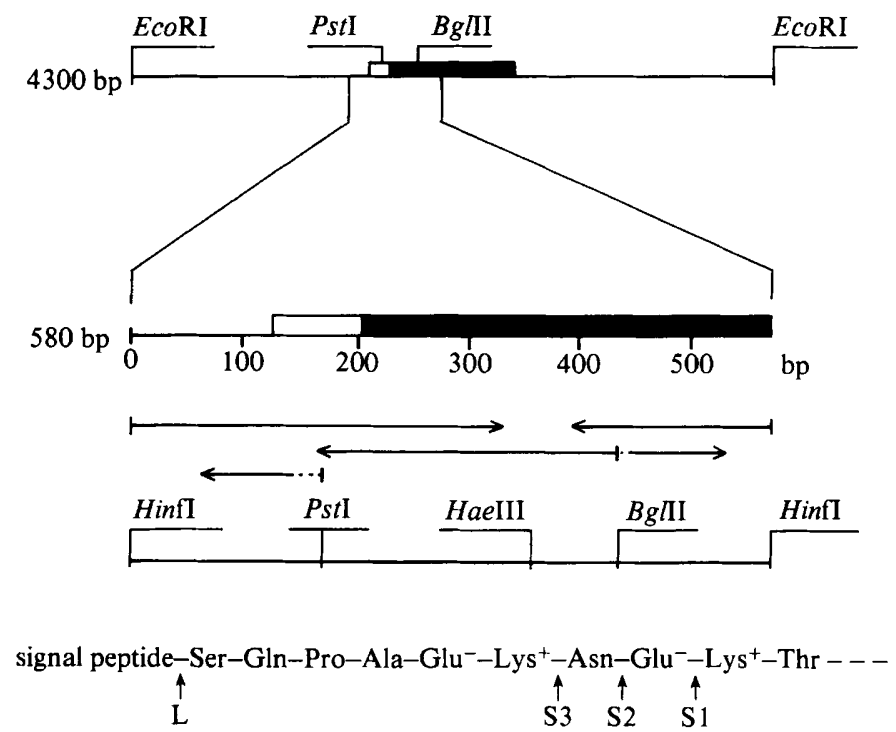

Fig. 3. Restriction map of the penicillinase gene region for B. licheniformis ATCC 9945 A, a strategy for DNA sequencing, and amino acid sequence of the $\mathrm{NH}_{2}$-terminal portion of penicillinase. The structural gene of penicillinase is indicated as a box, the open section corresponding to the signal peptide region, and the filled section to the extracellular penicillinase region. The stretches of DNA sequenced are indicated by full arrows, and dotted lines show non-sequenced regions. Vertical arrows at L, S3, S2 and S1 indicate proteolytic cleavage sites.

ATCC 9945 A was quite similar to that from $B$. licheniformis $749 / \mathrm{C}$ with respect to the molecular size and restriction map, the nucleotide sequence of pen $P$ from strain 749/C (Neugebauer et al., 1981) was considered relevant. The DNA sequencing strategy for the $\mathrm{NH}_{2}$-terminal region of penicillinase from $B$. licheniformis ATCC 9945A is summarized in Fig. 3. The Hinf I-digested fragment $(580 \mathrm{bp})$ containing the desired region was isolated by PAGE and further analysed.

The nucleotide sequence of this $580 \mathrm{bp}$ fragment was completely identical with that from strain $749 / \mathrm{C}$ (Neugebauer et al., 1981). It has also been reported that penicillinase produced by $B$. licheniformis $9945 \mathrm{~A}$ was enzymically and immunologically indistinguishable from that produced by strain 749 (Sherratt \& Collins, 1973; Imanaka et al., 1981). Accordingly, it might be inferred that the $\mathrm{NH}_{2}$-terminal amino acid sequence and their processing were the same for extracellular penicillinases from strains ATCC $9945 \mathrm{~A}$ and $749 / \mathrm{C}$ of $B$. licheniformis. The $\mathrm{NH}_{2}-$ terminal amino acid sequence derived from the nucleotide sequence for $B$. licheniformis ATCC $9945 \mathrm{~A}$ is shown in Fig. 3 ; it is identical to the sequence already published by Neugebauer et al. (1981) for B. licheniformis $749 / C$.

\section{Determination of the $\mathrm{NH}_{2}$-terminal amino acid}

Extracellular penicillinases from $B$. licheniformis and B. subtilis were analysed for their $\mathrm{NH}_{2}-$ terminal amino acids. Figure $4(a)$ shows a representation of the chromatogram obtained for penicillinase from $B$. licheniformis. By reference to the chromatograms presented by Gray (1972) the unknown spot on the left-hand chromatogram was judged to be that for lysine. Hence the $\mathrm{NH}_{2}$-terminal amino acids for the penicillinase from $B$. licheniformis were serine and lysine.

The $\mathrm{NH}_{2}$-terminal amino acids for the penicillinase from $B$. subtilis are represented in Fig. $4(b)$. The unknown spot on the left-hand chromatogram was identified as that for aspartic acid. Thus the three spots on the right-hand side correspond to serine, glutamic acid and aspartic acid. However, since in this procedure $\mathrm{NH}_{2}$-terminal glutamine or asparagine are converted to dansyl-glutamic acid and dansyl-aspartic acid, respectively, the amides cannot be distinguished from the unsubstituted acids in these experiments. However, from inspection of the previous 
(a) B. licheniformis M015-1(pTTB32):

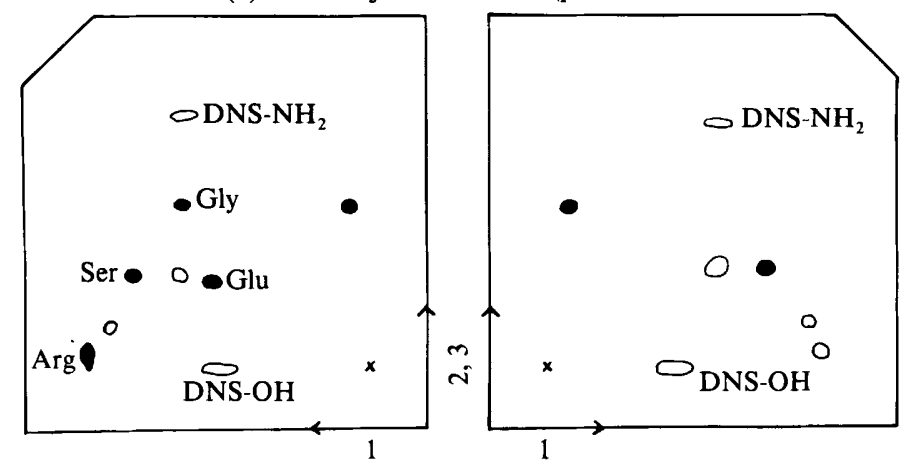

(b) B. subtilis MI112(pTTB32):

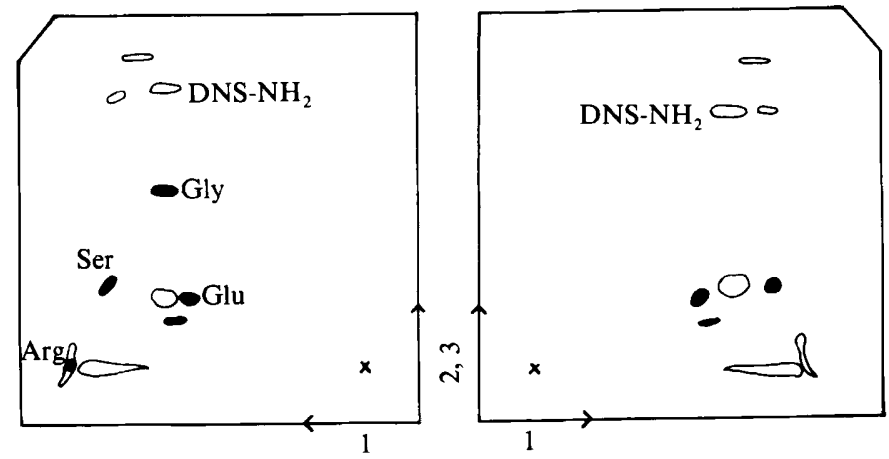

Fig. 4. TLC of dansyl amino acids on polyamide sheets. Penicillinases from B. licheniformis M015-1 (pTTB32) (a) and $B$. subtilis MI12(pTTB32) (b) were analysed. Left-hand side for each: the chromatogram for a mixture of the standards and a sample of penicillinase. Right-hand side for each: chromatogram of the penicillinase sample only. The crosses on the sketches represent the origins. The filled areas correspond to standard dansyl amino acids; the open areas are the derivatives of dansyl chloride such as dansylamide (DNS- $\mathrm{NH}_{2}$ ) and dansyl acid (DNS-OH) (Gray, 1972). Numbers 1, 2 and 3 with arrows indicate the directions of first, second and third separations, respectively.

data on the molecular weight of the penicillinase ( 30500 for exo-large and 29500 for exo-small), the isoelectric point (5.00-5.04) and the amino acid sequence (Fig. 3), the most probable $\mathrm{NH}_{2}$ terminal amino acids for exo-small penicillinase from $B$. subtilis were taken as glutamic acid and asparagine (see Discussion).

\section{DISCUSSION}

Some properties of extracellular penicillinases produced by strains $749 / \mathrm{C}$ and ATCC $9945 \mathrm{~A}$ of $B$. licheniformis and by $B$. subtilis are summarized in Table 3 . Based on the similarity of

Table 3. Properties of extracellular penicillinase

\begin{tabular}{|c|c|c|c|}
\hline Strain & $\begin{array}{c}\text { Molecular } \\
\text { weight }\end{array}$ & $\begin{array}{l}\text { Isoelectric } \\
\text { point }\end{array}$ & $\begin{array}{l}\mathrm{NH}_{2} \text {-terminal } \\
\text { residue }\end{array}$ \\
\hline heniformis & $30500^{*}$ & $4.95-5.05 \dagger$ & Sert+ \\
\hline$/ \mathrm{C}$ & $29500^{*}$ & $5 \cdot 10 \dagger$ & Lys $\ddagger$ \\
\hline heniformis & 30500 & $\sim 5.00$ & Ser \\
\hline $\begin{array}{l}\text { TCC 9945A } \\
015-1(\text { pTTB32) }\end{array}$ & 29500 & $\sim 5 \cdot 13$ & Lys \\
\hline $\begin{array}{l}\text { subtilis } \\
\text { I112(pTTB32) }\end{array}$ & $\begin{array}{l}30500 \\
29500\end{array}$ & $5 \cdot 00-5 \cdot 04$ & $\begin{array}{l}\text { Ser } \\
\text { Glu, Asn }\end{array}$ \\
\hline
\end{tabular}

* Izui et al. (1980). † Crane \& Lampen (1974). $\ddagger$ Nielsen \& Lampen (1982). 
proteins from $B$. licheniformis $749 / \mathrm{C}$ and ATCC 9945A, the cleavage sites of exo-large and exosmall penicillinases for strain ATCC 9945A were designated as L and S1 in Fig. 3. It is evident that the exo-large penicillinase contains a more negatively-charged sequence than the exo-small enzyme. Consequently, the experimental fact that the isoelectric point for the exo-large enzyme (around 5.00) was lower than that $(5 \cdot 10-5 \cdot 13)$ for the exo-small enzyme (Table 3) could be explained by the slight difference in the negative charge between the exo-large and exo-small enzymes.

On the other hand, the cleavage sites of exo-large and exo-small enzymes from $B$. subtilis were most likely to be L, and S2 or S3, respectively (Fig. 3). On this basis, the experimental findings of nearly the same isoelectric points for these enzymes and their difference of molecular weight were understandable, because one positively-charged and one negatively-charged amino acid were simultaneously deleted from the exo-large enzyme, resulting in no charge variation between the exo-large and exo-small penicillinases.

Aiyappa et al. (1977) reported that membrane penicillinase of $B$. licheniformis $749 / C$ was converted to extracellular enzyme by a penicillinase-releasing protease. Furthermore, Izui et al. (1980) have shown that exo-large penicillinase of the same strain was converted to exo-small form by proteolytic cleavage. The different cleavage of extracellular penicillinase produced by $B$. subtilis and $B$. licheniformis ATCC 9945A might have been due to the difference in hostspecific proteases. Indeed, when the culture broth of $B$. licheniformis ATCC $9945 \mathrm{~A}$ was kept at pH 9.0 for 30 min prior to the enzyme preparation, a new exo-small enzyme (mol. wt 28000) appeared. In contrast, such a new enzyme did not appear for $B$. subtilis after the same alkaline treatment (data not shown). These results support the above-mentioned proposal.

Our results emphasize that it is important that any peptide product should be carefully examined when it is produced by different host strains, even if the product is expressed from the same structural gene.

\section{REFERENCES}

Aiyappa, P. S., Traficante, L. J. \& Lampen, J. O. (1977). Penicillinase-releasing protease of Bacillus licheniformis: purification and general properties. Journal of Bacteriology 129, 191-197.

Crane, L. J. \& LAMPEN, J. O. (1974). Bacillus licheniformis $749 / \mathrm{C}$ plasma membrane penicillinase, a hydrophobic polar protein. Archives of Biochemistry and Biophysics 160, 655-666.

GRAY, W. R. (1972). End-group analysis using dansyl chloride. Methods in Enzymology 25, 121-138.

Imanaka, T., Tsunekawa, H. \& Aiba, S. (1980). Phenotypic stability of trp operon recombinant plasmids in Escherichia coli. Journal of General Microbiology 118, 253-261.

Imanaka, T., Tanaka, T., Tsunekawa, H. \& Aiba, S. (1981). Cloning of the genes for penicillinase, penP and penI, of Bacillus licheniformis in some vector plasmids and their expression in Escherichia coli, Bacillus subtilis, and Bacillus licheniformis. Journal of Bacteriology 147, 776-786.

imanaka, T., Fuji, M., ARamori, I. \& Aiba, S. (1982). Transformation of Bacillus stearothermophilus with plasmid DNA and characterization of shuttle vector plasmids between Bacillus stearothermophilus and Bacillus subtilis. Journal of Bacteriology 149, 824830.

Izui, K., Nielsen, J. B. K., Caulfield, M. P. \& LAMPEN, J. O. (1980). Large exopenicillinase, initial extracellular form detected in culture of Bacillus licheniformis. Biochemistry 19, 1882-1886.

LAEMMLI, U. K. (1970). Cleavage of structural proteins during the assembly of the head of bacteriophage T4. Nature, London 227, 680-685.

MaXam, A. M. \& Gilbert, W. (1977). A new method for sequencing DNA. Proceedings of the National Academy of Sciences of the United States of America 74, 560-564.

Neugebauer, K., Sprengel, R. \& Schaller, H. (1981). Penicillinase from Bacillus licheniformis: nucleotide sequence of the gene and implications for the biosynthesis of a secretory protein in a Grampositive bacterium. Nucleic Acids Research 9, 25772588.

Nielsen, J. B. K. \& Lampen, J. O. (1982). Membranebound penicillinases in Gram-positive bacteria. Journal of Biological Chemistry 257, 4490-4495.

Pollock, M. R. (1965). Purification and properties of penicillinases from two strains of Bacillus licheniformis: a chemical, physicochemical and physiological comparison. Biochemical Journal 94, 666-675.

Sarvas, M., Hirth, K. P., Fuchs, E. \& Simons, K. (1978). A precursor form of the penicillinase from Bacillus licheniformis. FEBS Letters 95, 76-80.

SherratT, D. J. \& Collins, J. F. (1973). Analysis by transformation of the penicillinase system in Bacillus licheniformis. Journal of General Microbiology 76, 217-230.

Simons, K., Sarvas, M., Garoff, H. \& Helenius, A. (1978). Membrane-bound and secreted forms of penicillinase from Bacillus licheniformis. Journal of Molecular Biology 126, 673-690.

Smirh, W. P., TAI, P. C. \& Davis, B. D. (1981). Bacillus licheniformis penicillinase: cleavages and attachment of lipid during cotranslational secretion. Proceedings of the National Academy of Sciences of the United States of America 78, 3501-3505. 
WeBer, K. \& Osborn, M. (1969). The reliability of molecular weight determination by dodecylsulfate polyacrylamide gel electrophoresis. Journal of Biological Chemistry 244, 4406-4412.
Yamamoto, S. \& Lampen, J. O. (1976). Purification of plasma membrane penicillinase from Bacillus licheniformis $749 / \mathrm{C}$ and comparison with exoenzyme. Journal of Biological Chemistry 251, 4095-4101. 